\title{
The Earnings Differential between Formal and Informal Employees in Urban China
}

\author{
Hong Zuo'
}

ABSTRACT Few studies in the field of labor economics have analyzed the earnings differential between formal
and informal employees in urban China. Due to data limitations, previous studies on this subject have
not yielded accurate and widely acceptable results. This study seeks to obtain more accurate results
by analyzing the earnings differential based on the conceptual framework of informal employment
developed by the 17th International Conference of Labor Statisticians. We analyzed data from the
2006 Chinese General Social Survey, using the Lee model to correct for selection bias and decompos-
ing the earnings differential between formal and informal employees in urban China in terms of the
effects of employee characteristics, employment, and working hours. The latter two of these com-
prise the segmentation effect. We found that only $33 \%$ of the observed earnings differential can be
explained by employee characteristics; the remaining $67 \%$ is attributable to the segmentation effect.
The working hours effect narrows the earnings differential. Based on the results of our analysis, we
conclude that informal employees in urban China, especially female informal employees, suffer from
segmentation and that policies to address segmentation issues are needed.

KEY WORDS: $\quad$ informal employment; earnings differential; segmentation; decomposition

JEL Classification: J16, J21, J31

${ }^{1}$ Nagoya University, Japan; Zhejiang University, China.

\section{Introduction}

In recent years, informal employment has become a significant phenomenon, not only in developing countries but also in developed countries, as reflected by increasing proportions of workers who are informally employed. Between $20 \%$ and $30 \%$ of all workers in developed countries and more than $40 \%$ of workers in developing countries are engaged in informal employment (Hu \& Yang, 2001). However, informal employees suffer from low wages, lack of social protection, and other problems (International Labor Organization [ILO], 2002).

Correspondence concerning this article should be addressed to: Hong Zuo, Furo-cho, Chikusa-ku, Nagoya, 464-8601; No. 388, Yuhangtang Road, Xihu District, Hangzhou, China. 310058., e-mail: sakou157@yahoo.co.jp
In China, informal employment is an important and urgent issue. When China transitioned to a marketoriented economy, to address the problem of overallocation of labor to the agriculture sector, the Hukou System was modified to permit more flexibility. The state policy concerning the control of rural worker mobility has gradually changed since 1978. According to Meng (2003), from 1958 to 1978, the movement of rural residents to urban areas was forbidden. This was followed by a period of controlled movement (1979-1983), a period during which such movement was allowed (1984-1988), a period of controlled random movement (1989-1991), a period of regulated movement (1992-2000), and a period since 2000 during which a fair movement policy has prevailed. From the 1980s through the early 2000s, millions of surplus rural laborers migrated to urban areas in search of 
employment, and at the same time, millions of former state-sector employees were laid off (Cooke, 2008). As there were not enough formal jobs for all of these people, informal employment came to exist and has experienced a steady increase in China since the 1990s. Informal employment is becoming the main mode of employment in China ( $\mathrm{Hu} \&$ Yang, 2001). However, informally employed workers are at a disadvantage in various respects, such as in their work conditions and social welfare level, compared to formal workers $(\mathrm{Wu}$ \& Cai, 2006). Therefore, labor market policy changes in China are called for to address informal employment issues.

Aspects of informal employment, including its definition (Hu \& Yang, 2001; Wang, 2006), scale (Wu \& Cai, 2006), and wage differential (Deng, 2009) have been researched by many Chinese scholars. Although several studies have addressed informal employment in China on a macro scale, few if any had sufficient micro data available to support their findings, and these studies were not structured in accordance with the internationally accepted framework of informal employment. These previous studies were thus not able to accurately characterize the earnings differential between formal and informal employment in China and were also unable to make comparisons with international research on informal employment.

To tackle the problems confronted by previous researchers and to provide more accurate and widely acceptable results, we analyzed the earnings differential between formal and informal employees in urban China, utilizing data from the 2006 Chinese General Social Survey (CGSS), a relatively new nationwide sample and four-stage stratified sampling scheme that provides abundant job information that can be analyzed using the International Conference of Labor Statisticians (ICLS) framework, using an approach based on this conceptual framework of informal employment developed by the 17th ICLS. Lee's model (1983) was employed to correct for possible selection bias, and the effect of working hours on the earnings differential is considered. Earnings differential decompositions have been widely used in previous studies on the existence and extent of labor market segmentation (Dickens \& Lang, 1985) and specifically in studies on informal employment (Du, Cai \& Wang, 2008). We follow the examples of previous studies.
The results of this study are presented as follows. In Section 2, we present the results of a literature review of informal employment in China. In Section 3 , we present the conceptual framework of informal employment developed by the 17th ICLS and describe the data and methodology. In Section 4, we present an overview of formal and informal employees in urban China. In Section 5, we discuss the results of the estimation and decomposition. We lastly offer concluding remarks in Section 6.

\section{Literature review}

Bernabè (2002) defined informal employees as individuals in any of the following situations in either their primary or secondary jobs: (1) self-employed workers and employees in household enterprises; (2) (unpaid) contributing family workers; (3) non-regular employees; (4) persons employed casually, temporarily or seasonally; or (5) employees engaged in "left-hand work" (earnings informal income at their formal workplaces).

Günther and Launov (2011) studied the structure of the urban labor market in the Côte d'Ivoire. They formulated an econometric model of the labor market that provided an intuitive approach to analyzing whether employment in the informal sector of the labor market was voluntary or a strategy of last resort. Their results show that the informal sector is composed of two segments, with a distinct wage equation for each segment.

The definition of informal employment differs among scholars in China. Hu and Yang (2001) defined informally employed workers as follows: (1) workers engaged in the informal sector, and (2) workers with informal employment in the formal sector. The informal sector includes small and medium enterprises, family enterprises, and self-owned small businesses. Informally employed workers in the formal sector are workers who are temporarily employed by the formal sector. Corporate enterprises and institutions, government agencies, and social organizations were defined by $\mathrm{Hu}$ and Yang as making up the formal sector. $\mathrm{Hu}$ and Yang concluded that developing informal employment in China is an important way to avoid high unemployment and that it will become the main mode of employment in China in the future.

Wang (2006) proposed a legal definition of informally employed workers as those engaged in informal 18 

China has thus far lacked the data necessary to analyze informal employment, the definitions used in previous studies are not totally satisfactory.

According to the ICLS framework, there are three standards by which to judge whether a worker is in formal or informal employment. The first standard is the production unit to which they belong. Production units are classified into three groups: formal-sector enterprises, informal-sector enterprises, and households. The second standard is their job status. According to the International Classification by Status in Employment 93 (ICSE-93, ILO), employment status is classified as follows: self-employed workers, employers, contributing family workers, employees, members of producers' cooperatives, and agricultural workers. The third standard is the nature of the job, i.e., whether the type of job a person holds is a formal or informal job.

Considering the differences in work conditions and social welfare levels, in this study, we consider the following to be components of the formal sector in terms of production units: party and governmental organizations; state-owned or state-shareholding enterprises; collective or collective-shareholding enterprises; state-owned or collectively owned non-profit institutions; enterprises in Hong Kong, Macao, or Taiwan; foreign capital enterprises; and social groups. The self-employed, private enterprises, and other enterprises are considered part of the informal sector, in terms of production units. Following ILO (Hussmanns, 2004), workers in firms with fewer than 10 employees are considered to be working in the informal sector, and because of data limitations, these workers are treated as informal employees. We consider the nature of the job to be formal if the worker has an employment contract or if his employment is registered with the government. More details on the definition of informal employment are given by Zuo (2013).

According to the definition described above, there are 983 formal employees and 1,213 informal employees in our database. As stated in the literature review, Deng defined informal workers as workers in private and individually owned enterprises (with fewer than 100 employees), the self-employed, and workers who do not have a long-term contracts. Applying his definition to our data set, we found that there were 287 formal employees and 1,916 informal employees in our sample. Obviously, his definition overestimates the extent of informal employment.

\section{Data}

The data used in this analysis were drawn from the 2006 Chinese General Social Survey (CGSS). This survey was conducted jointly by the Survey Research Center of the Hong Kong University of Science and Technology and the Sociology Department of the People's University of China. A total of 10,000 households from 28 provinces and cities in China were randomly selected for this survey, and one family member between the ages of 18 and 69 was randomly picked from each of the selected households to participate in the survey. Unlike other survey data, such as the Chinese Household Income Project (CHIP), the 2006 CGSS is a relatively new nationwide sample and four-stage stratified sampling scheme that provides abundant job information that can be analyzed using the ICLS framework.

\section{Methodology}

As some workers in the samples were unemployed, their earnings were not observed; therefore, selection bias could be an issue. In this study, we adopted the Lee (1983) approach to correct for this selection bias. A multinomial logit model was estimated at the first stage of the Lee model. The results of this first stage (the employment status selection equation) are not discussed in this study, as the focus of this study is on the decomposition of the earnings differential between formal and informal workers. Zuo (2013) discussed the selection equation using similar workers' data for China. The results of the second stage of the Lee model (the unbiased hourly earnings functions and working hour functions for formal and informal employees) are used to decompose the monthly earnings differential between formal and informal employees.

Because the classification of employment status in this study was not binary, we adopted Lee's (1983) model rather than Heckman's model (1979) to correct for selection bias. The four employment status conditions considered are as follows: formal employees, informal employees, self-employed workers and the unemployed. Oaxaca-Blinder's decomposition approach is widely used to separate the earnings differential into two components. However, this approach cannot be applied to decomposing the earnings differential effects into three parts: difference in characteristics (e.g., age, sex, education and so on), differences in employment (i.e., formally or informally employed), and dif- 
Table 1. Overview of Formal and Informal Employees in Urban China (\%) (2006)

\begin{tabular}{|c|c|c|c|}
\hline & & Formal employees & Informal employees \\
\hline Demographics & Male & 57.78 & 52.84 \\
\hline \multirow[t]{5}{*}{ Age } & $18-29$ years & 30.42 & 29.68 \\
\hline & 30-39 years & 36.01 & 29.93 \\
\hline & 40-49 years & 24.42 & 28.36 \\
\hline & $50-59$ years & 8.85 & 10.47 \\
\hline & 60-69 years & 0.31 & 1.57 \\
\hline \multirow[t]{4}{*}{ Total education years } & $0-6$ years & 1.93 & 8.99 \\
\hline & $7-12$ years & 58.80 & 63.15 \\
\hline & $13-16$ years & 35.40 & 25.39 \\
\hline & $17-22$ years & 3.87 & 2.47 \\
\hline \multirow[t]{5}{*}{ Location } & East region & 52.49 & 46.66 \\
\hline & Middle region & 31.94 & 33.22 \\
\hline & West region & 15.56 & 20.12 \\
\hline & Large city & 50.66 & 43.78 \\
\hline & Immigrant & 11.19 & 16.49 \\
\hline \multirow[t]{7}{*}{ Firm size } & Not reported & 18.51 & 18.47 \\
\hline & $0-9$ & & 16.49 \\
\hline & $10-15$ & 3.15 & 7.67 \\
\hline & $16-49$ & 9.36 & 15.83 \\
\hline & $50-99$ & 11.09 & 8.74 \\
\hline & $100-499$ & 28.38 & 19.21 \\
\hline & 500 or more & 29.50 & 13.60 \\
\hline \multirow[t]{5}{*}{ Occupation } & Managerial & 8.55 & 8.82 \\
\hline & Professional & 23.80 & 18.96 \\
\hline & Technical & 19.74 & 19.04 \\
\hline & Clerical & 12.51 & 21.27 \\
\hline & Skilled agricultural & 35.40 & 31.90 \\
\hline \multirow[t]{2}{*}{ Industry } & Manufacturing & 38.13 & 26.82 \\
\hline & Services & 61.87 & 73.18 \\
\hline Total (number) & & 983 & 1213 \\
\hline
\end{tabular}

Notes:

The author calculated the values in this table using data from the 2006 Chinese General Social Survey.

ference in hours worked (i.e., monthly working hours). To conduct such decomposition, the extension of the Oaxaca-Blinder approach proposed by Bourguignon, Fournier and Gurgand (2001) was used in this analysis.

The decomposition model of Bourguignon et al. can be explained as follows. Let $\mathrm{F}$ represent formal employees, and let I represent informal employees. The monthly earnings of informal employee i can be written as follows:
$\mathrm{y}_{\mathrm{I}}^{\mathrm{i}}=\mathrm{h}_{\mathrm{I}}^{\mathrm{i}} \times \exp \left(\ln \mathrm{w}_{\mathrm{I}}^{\mathrm{i}}\right)=\mathrm{H}\left(\mathrm{z}_{\mathrm{I}}^{\mathrm{i}}, \eta_{\mathrm{I}}^{\mathrm{i}} \gamma_{\mathrm{I}}\right) \times \exp \left(\ln \mathrm{W}\left(\mathrm{x}_{\mathrm{I}}^{\mathrm{i}} \varepsilon_{\mathrm{I}}^{\mathrm{i}} \beta_{\mathrm{I}}\right)\right)$

where $\mathrm{y}_{\mathrm{I}}^{\mathrm{i}}, \mathrm{h}_{\mathrm{I}}^{\mathrm{i}}$ and $\mathrm{w}_{\mathrm{I}}^{\mathrm{i}}$ are the monthly earnings, hours worked, and hourly earnings, respectively of informal employee i.

Hourly earnings can be expressed as follows:

$\ln \mathrm{w}_{\mathrm{I}}^{\mathrm{i}}=\mathrm{W}\left(\mathrm{x}_{\mathrm{I}}^{\mathrm{i}}, \varepsilon_{\mathrm{I}}^{\mathrm{i}} \beta_{\mathrm{I}}\right)$ 
with individual observable characteristics $\left(\mathrm{x}_{\mathrm{I}}^{\mathrm{i}}\right)$, unobservable characteristics $\left(\varepsilon_{\mathrm{I}}^{\mathrm{i}}\right)$, and parameters $\beta_{\mathrm{I}}$ as arguments.

Working hours can be expressed as $\mathrm{h}_{\mathrm{I}}^{\mathrm{i}}=\mathrm{H}\left(\mathrm{z}_{\mathrm{I}}^{\mathrm{i}}, \eta_{\mathrm{I}}^{\mathrm{i}}\right.$ $\left.\gamma_{I}\right)$, where $z_{I}^{i}$ and $\eta_{I}^{i}$ are individual observable and unobservable characteristics, respectively, and $\gamma_{\mathrm{I}}$ are the coefficients estimated.

Similarly, the monthly earnings of formal employees can be written as follows:

$\mathrm{y}_{\mathrm{F}}^{\mathrm{i}}=\mathrm{h}_{\mathrm{F}}^{\mathrm{i}} \times \exp \left(\ln \mathrm{w}_{\mathrm{F}}^{\mathrm{i}}\right)=\mathrm{H}\left(\mathrm{z}_{\mathrm{F}}^{\mathrm{i}}, \eta_{\mathrm{F}}^{\mathrm{i}} \gamma_{\mathrm{F}}\right) \times \exp \left(\ln \mathrm{W}\left(\mathrm{x}_{\mathrm{F}}^{\mathrm{i}}, \varepsilon_{\mathrm{F}}^{\mathrm{i}} \beta_{\mathrm{F}}\right)\right)$

The monthly earnings differential between formal and informal employees can be decomposed into three parts:

(1) Pure differences in characteristics (e.g., sex, education): $\mathrm{H}\left(\mathrm{z}_{\mathrm{F}}^{\mathrm{i}}, \eta_{\mathrm{F}}^{\mathrm{i}} \gamma_{\mathrm{F}}\right) \times \mathrm{W}\left(\mathrm{x}_{\mathrm{F}}^{\mathrm{i}} \varepsilon_{\mathrm{F}}^{\mathrm{i}} \beta_{\mathrm{F}}\right)-\mathrm{H}\left(\mathrm{z}_{\mathrm{I}}^{\mathrm{i}}, \eta_{\mathrm{I}}^{\mathrm{i}}, \gamma_{\mathrm{F}}\right) \times \mathrm{W}\left(\mathrm{x}_{\mathrm{I}}^{\mathrm{i}}, \varepsilon_{\mathrm{I}}^{\mathrm{i}}, \beta_{\mathrm{F}}\right)$

(2) Pure differences in employment (i.e., formally or informally employed):

$\mathrm{H}\left(\mathrm{z}_{\mathrm{I}}^{\mathrm{i}}, \eta_{\mathrm{I}}^{\mathrm{i}} \gamma_{\mathrm{F}}\right) \times \mathrm{W}\left(\mathrm{x}_{\mathrm{I}}^{\mathrm{i}} \varepsilon_{\mathrm{I}}^{\mathrm{i}}, \beta_{\mathrm{F}}\right)-\mathrm{H}\left(\mathrm{z}_{\mathrm{I}}^{\mathrm{i}}, \eta_{\mathrm{I}}^{\mathrm{i}}, \gamma_{\mathrm{F}}\right) \times \mathrm{W}\left(\mathrm{x}_{\mathrm{I},}^{\mathrm{i}} \varepsilon_{\mathrm{I}}^{\mathrm{i}}, \beta_{\mathrm{I}}\right)$

(3) Pure differences in hours worked (i.e., monthly working hours):

$\mathrm{H}\left(\mathrm{z}_{\mathrm{I}}^{\mathrm{i}}, \eta_{\mathrm{I}}^{\mathrm{i}}, \gamma_{\mathrm{F}}\right) \times \mathrm{W}\left(\mathrm{x}_{\mathrm{I}}^{\mathrm{i}} \varepsilon_{\mathrm{I}}^{\mathrm{i}}, \beta_{\mathrm{I}}\right)-\mathrm{H}\left(\mathrm{z}_{\mathrm{I}}^{\mathrm{i}}, \eta_{\mathrm{I}}^{\mathrm{i}}, \gamma_{\mathrm{I}}\right) \times \mathrm{W}\left(\mathrm{x}_{\mathrm{I}}^{\mathrm{i}} \varepsilon_{\mathrm{I}}^{\mathrm{i}} \beta_{\mathrm{I}}\right)$

The latter two, the difference in employment and the difference in hours worked, comprise the segmentation effect. We report the mean of the alternative decomposition results.

\section{Overview of Formal and Informal Employees in Urban China}

We present an overview of formal and informal employees by indicating the proportion of workers in each group (see Table 1). There are six variables that detail the characteristics for all employed individuals: demographics, total years of education, location, firm size, occupation, and industry.

As Table 1 shows, males occupy larger proportions of both the formal and informal employee groups than females. Young workers below the age of 40 are more likely to be formal employees, while workers above age 40 are more likely to be informal employees. Most formal employees have more than 7 years of education, while $63 \%$ of informal employees have between 7 and 12 years of education.

Workers in the east account for the vast majority of both formal and informal employees (more than
$45 \%)$, followed by workers in the middle and west regions. Approximately $56 \%$ of informal employees are not from large cities, and more than $80 \%$ of all of the workers are non-immigrants.

Nearly $40 \%$ of informal employees are in enterprises that employ fewer than 50 workers. In contrast, more than $57 \%$ of formal employees are in enterprises that employ more than 100 workers.

In terms of occupation, proportionally more professional and technical workers are formal employees than informal employees. A larger proportion of informal employees are clerical workers. The majority of formal and informal employees work in services, although the percentage is higher for informal employees.

\section{Empirical results}

\section{Hourly earnings functions}

The hourly earnings are summarized in Table 2. We only comment on the marginal effects that are statistically significant. Male employees enjoy hourly earnings that are approximately $9 \%$ higher than female employees, meaning that an hourly earnings differential by gender exists among both formal and informal employees.

Higher educational attainment leads to approximately $6 \%$ higher hourly earnings for formal employees, and it is also significant and slightly higher, at 7\%, for informal employees. This indicates that education is rewarded for both informal and formal employees in urban China.

Hourly earnings differ greatly for employees from different regions. Hourly earnings are $40 \%$ for formal employees and approximately 30\% higher for informal employees in the east than in the middle and western regions. Formal and informal employees from large cities receive hourly earnings more than $20 \%$ higher than employees from smaller areas. Immigrant employees receive higher hourly earnings than non-immigrants.

Informal employees in firms employing fewer than 50 workers earn significantly less than employees in the reference group; i.e., those in firms with more than 500 workers. Informal employees in firms with fewer than 10 workers earn $42 \%$ less per hour than those in the reference group. For formal employees, all other groups of workers earn significantly less than those in 
Table 2. Estimating Log Hourly Earnings of Formal and Informal Employees in Urban China (2006)

\begin{tabular}{|c|c|c|c|}
\hline & & Formal employees & Informal employees \\
\hline Demographics & Male (d) & $0.088(2.14)^{* *}$ & $0.101(2.54)^{* * *}$ \\
\hline \multirow[t]{5}{*}{ Age } & $18-29(d)$ & $0.496(0.87)$ & $0.287(1.03)$ \\
\hline & $30-39(d)$ & $0.467(0.83)$ & $0.258(0.92)$ \\
\hline & $40-49(d)$ & $0.468(0.83)$ & $0.275(0.99)$ \\
\hline & $50-59(d)$ & $0.686(1.21)$ & $0.323(1.16)$ \\
\hline & $60-69(d)$ & Reference & Reference \\
\hline Experience & & $0.010(0.98)$ & $0.020(2.59) * * *$ \\
\hline Experience squared & & $-0.000(-0.86)$ & $-0.000(-1.54)$ \\
\hline Total education years & & $0.058(6.05)^{* * *}$ & $0.070(9.65)^{* * *}$ \\
\hline \multirow[t]{5}{*}{ Location } & East region (d) & Reference & Reference \\
\hline & Middle region (d) & $-0.409(-9.43)^{* * *}$ & $-0.259(-5.35)^{* * *}$ \\
\hline & West region (d) & $-0.434(-6.80) * * *$ & $-0.335(-6.74)^{* * *}$ \\
\hline & Large city (d) & $0.209(5.00) * * *$ & $0.229(5.91)^{* * *}$ \\
\hline & Immigrant (d) & $0.211(3.32)^{* * *}$ & $0.185(3.16)^{* * *}$ \\
\hline \multirow[t]{7}{*}{ Firm size } & Not reported (d) & $-0.183(-2.87)^{* * *}$ & $-0.061(-0.80)$ \\
\hline & $0-9(d)$ & & $-0.421(-5.37)^{* * *}$ \\
\hline & $10-15(d)$ & $-0.279(-2.08) * *$ & $-0.252(-2.61) * * *$ \\
\hline & $16-49(d)$ & $-0.162(-1.78)^{*}$ & $-0.167(-1.93) * *$ \\
\hline & 50-99 (d) & $-0.175(-2.59) * * *$ & $-0.036(-0.44)$ \\
\hline & $100-499$ (d) & $-0.162(-3.00) * * *$ & $-0.031(-0.47)$ \\
\hline & 500 or more $(d)$ & Reference & Reference \\
\hline \multirow[t]{5}{*}{ Occupation } & Managerial (d) & $0.454(4.92)^{* * *}$ & $0.276(2.94)^{* * *}$ \\
\hline & Professional (d) & $0.178(2.63)^{* * *}$ & $0.112(1.82)^{*}$ \\
\hline & Technical (d) & $-0.056(-0.88)$ & $-0.033(-0.53)$ \\
\hline & Clerical (d) & $-0.082(-1.12)$ & $-0.086(-1.42)$ \\
\hline & Skilled agricultural (d) & Reference & Reference \\
\hline \multirow[t]{2}{*}{ Industry } & Manufacturing (d) & Reference & Reference \\
\hline & Services (d) & $0.117(2.38)^{* *}$ & $0.070(1.43)$ \\
\hline Pseudo R-squared & & 0.535 & 0.535 \\
\hline Constant & & $0.953(1.58)$ & $0.586(1.90)^{*}$ \\
\hline Number of observations & & 983 & 1213 \\
\hline
\end{tabular}

Notes:

The author calculated the values in this table using data from the 2006 Chinese General Social Survey.

$*^{* * *},{ }^{* *}$, and ${ }^{*}$ denote statistical significance at the $1 \%, 5 \%$, and $10 \%$ levels, respectively; (d) represents a discrete change in the dummy variable from $0-1$; data in parentheses are the $Z$ values.

the reference group, with workers in firms employing fewer than 15 workers earning the least.

Formal employees in managerial and professional occupations earn higher hourly earnings than skilled agricultural workers. For informal employees, it seems that occupations do not make much difference in hourly earnings, except for professional workers. For- mal employees engaged in services earn approximately $12 \%$ higher hourly earnings than formal employees in the manufacturing industry.

\section{The determinants of working hours}

The hourly earnings are summarized in Table 3. In addition, we only comment on the marginal effects that 
Table 3. Estimating Monthly Working Hours of Formal and Informal Employees in Urban China (2006)

\begin{tabular}{|c|c|c|c|}
\hline & & Formal employees & Informal employees \\
\hline Demographics & Male (d) & $10.335(3.93)^{* * *}$ & $11.217(3.68)^{* * *}$ \\
\hline Age & & $1.910(1.87)^{*}$ & $-2.042(-1.81)^{*}$ \\
\hline Age2 & & $-0.026(-1.87)^{*}$ & $0.018(1.21)$ \\
\hline Total education years & & $-1.720(-2.44)^{* *}$ & $-3.688(-6.01)^{* * *}$ \\
\hline \multirow[t]{5}{*}{ Location } & East region (d) & Reference & Reference \\
\hline & Middle region (d) & $5.863(1.76) *$ & $4.109(1.19)$ \\
\hline & West region (d) & $-1.066(-0.25)$ & $-2.700(-0.57)$ \\
\hline & Large city (d) & $-12.620(-4.15)^{* * *}$ & $-1.869(-0.62)$ \\
\hline & Immigrant (d) & $9.225(1.81) *$ & $15.124(3.15)^{* * *}$ \\
\hline \multirow[t]{7}{*}{ Firm size } & Not reported (d) & $0.378(0.10)$ & $10.821(1.82)^{*}$ \\
\hline & $0-9(d)$ & & $17.476(2.72)^{* * *}$ \\
\hline & $10-15(d)$ & $3.157(0.26)$ & $21.226(2.36)^{* *}$ \\
\hline & $16-49(d)$ & $-2.116(-0.35)$ & $15.515(2.10)^{* *}$ \\
\hline & 50-99 (d) & $5.170(0.93)$ & $6.235(0.93)$ \\
\hline & $100-499(d)$ & $7.235(1.89) *$ & $2.594(0.44)$ \\
\hline & 500 or more $(d)$ & Reference & Reference \\
\hline \multirow[t]{5}{*}{ Occupation } & Managerial (d) & $0.731(0.13)$ & $-3.647(-0.51)$ \\
\hline & Professional (d) & $1.392(0.30)$ & $-5.087(-1.04)$ \\
\hline & Technical (d) & $5.321(1.12)$ & $1.688(0.33)$ \\
\hline & Clerical (d) & $2.598(0.47)$ & $3.362(0.63)$ \\
\hline & Skilled agricultural (d) & Reference & Reference \\
\hline \multirow[t]{2}{*}{ Industry } & Manufacturing (d) & Reference & Reference \\
\hline & Services (d) & $-4.682(-1.32)$ & $-0.874(-0.22)$ \\
\hline Pseudo R-squared & & 0.526 & 0.526 \\
\hline Constant & & $160.697(7.17)^{* * * *}$ & $258.961(10.85)^{* * *}$ \\
\hline Number of observations & & 983 & 1213 \\
\hline
\end{tabular}

Notes:

The author calculated the values in this table using data from the 2006 Chinese General Social Survey.

(a) ${ }^{* *},{ }^{* *}$, and ${ }^{*}$ denote statistical significance at the $1 \%, 5 \%$, and $10 \%$ levels, respectively; (d) represents a discrete change in the dummy variable from $0-1$; data in parentheses are the $Z$ values.

are statistically significant. Men, both formal and informal employees, work approximately 11 hours per month more than women. Higher educational attainment leads to shorter working hours for both formal and informal employees and is more notable for informal employees.

Monthly working hours do not appear to differ for employees from different regions. Formal employees from large cities worked approximately 13 hours per month less than formal employees from smaller areas. Among informal employees, immigrant employees work more than 15 hours per month more than nonimmigrants.

Firm size does not make much difference in monthly working hours for formal employees, but the situation is much different for informal employees working in firms employing fewer than 50 workers. These informal employees work approximately 20 hours more per month than informal employees working in firms employing more than 500 workers.

Occupation does not make much difference in monthly working hours for either formal or informal employees. 
Table 4. Decomposition of Monthly Earnings Differential between Formal and Informal Employees in Urban China (2006)

\begin{tabular}{|c|c|c|c|c|c|c|}
\hline & \multicolumn{2}{|c|}{ Mean monthly earnings } & \multirow{3}{*}{$\begin{array}{c}\begin{array}{c}\text { Observed } \\
\text { differential }\end{array} \\
\text { Formal- } \\
\text { Informal }\end{array}$} & \multicolumn{3}{|c|}{$\begin{array}{l}\text { Effect on the observed earnings } \\
\text { differential of }\end{array}$} \\
\hline & \multirow{2}{*}{$\begin{array}{c}\text { Formal } \\
\text { employees }\end{array}$} & \multirow{2}{*}{$\begin{array}{l}\text { Informal } \\
\text { employees }\end{array}$} & & \multirow{2}{*}{$\begin{array}{c}\text { Characteristics } \\
\text { effect }\end{array}$} & \multicolumn{2}{|c|}{ Segmentation effect } \\
\hline & & & & & $\begin{array}{l}\text { Employment } \\
\text { effect }\end{array}$ & $\begin{array}{c}\text { Hours worked } \\
\text { effect }\end{array}$ \\
\hline \multirow[t]{2}{*}{ All employees } & 1808.6 & 1196.4 & 612.2 & 202.2 & 454.4 & -44.4 \\
\hline & & & & (33.0\%) & (74.3\%) & $(-7.3 \%)$ \\
\hline \multirow[t]{2}{*}{ Male employees } & 2038.1 & 1393.4 & 644.7 & 249.4 & 466.6 & -71.3 \\
\hline & & & & $(38.7 \%)$ & $(72.4 \%)$ & $(-11.1 \%)$ \\
\hline \multirow[t]{2}{*}{ Female employees } & 1414.2 & 1001.4 & 412.8 & 79.5 & 410.8 & -77.5 \\
\hline & & & & $(19.3 \%)$ & (99.5\%) & $(-18.8 \%)$ \\
\hline
\end{tabular}

Notes:

Decompositions are based on regressions results presented in tables 2 and 3; values refer to measured effects evaluated as earnings differences in 2006 Chinese Yuan; percentages in parentheses refer to measured effects as percentages of the observed total earnings differentials.

\section{Decomposing the Observed Earnings Differential}

Following the methodology presented in section 3, we use the earnings function and working hours function estimations to decompose the earnings differential into the pure difference-in-characteristics effect, the pure difference-in-employment effect, and the pure difference-in-hours-worked effect, with the latter two comprising the segmentation effect. The decomposition results are given in table 4 .

As Table 4 shows, the majority of the observed total earnings differential between formal and informal employees can be attributed to the difference-in-employment effect and the difference-in-hours-worked effect, rather than the differences in characteristics. Only $33 \%$ of the earnings differential between formal and informal employees can be explained by the differences in characteristics. The remaining $67 \%$ can be attributed to the segmentation effect, in which the pure employment effect dominates. In fact, longer hours worked by informal employees narrow the earnings differential between formal and informal employees, meaning that informal employees work more but earn less. This result confirms that the Chinese labor market is far from fully integrated, leading to a high earnings differential between formal and informal employees.

We also examined the earnings differential decomposition results by gender. For the male sub-sample, segmentation forces play a slightly less important role in explaining the earnings differential between formal and informal employees. However, in the female subsample, segmentation forces account for nearly $80 \%$ of the earnings differential between these two groups of employees, suggesting that female informal employees suffer most from segmentation.

\section{Concluding remarks}

The purpose of this research was to analyze the earnings differential between formal and informal workers in urban China based on the ICLS framework of informal employment, in an effort to obtain more accurate and widely acceptable results than previous studies. Using the 2006 CGSS micro data, we employed the approach of Bourguignon et al. (2001) to decompose the earnings differential between formal and informal employees in urban China into characteristics, employment and working hour effects, with the latter two comprising the segmentation effect. The possible selection bias problem was addressed using the Lee model. 
The main conclusions are that informal employees suffer from segmentation and work more but earn less, meaning that the earnings differential would be even larger if they worked the same number of hours as formal employees. This is especially true for female informal employees. Employment policies that address segmentation issues, e.g., gender segmentation, are needed in urban China. Segmentation, which prevents individuals from taking advantage of economic opportunities, must be identified and its adverse effects minimized. However, because we only have data for 2006 on hand, it was not possible in this study to assess how the situation has changed since 2006. This will be addressed in future research.

\section{References}

Bernabè, S. (2002). Informal Employment in Countries in Transition: A conceptual framework (CASE Paper No. 56). Centre for Analysis of Social Exclusion.

Bourguignon, F., Fournier, M., \& Gurgand, M. (2001). Fast Development with a Stable Income Distribution: Taiwan, 1979-1994. Review of Income and Wealth, 47 (2), 139-163.

Cooke, F. L. (2008, June, 25-26). Labor market regulations and informal employment in China: to what extent are workers protected? Paper presented at the Third Urban China Task Force Annual Meeting, University of Manchester, Manchester, UK.

Deng, Q. H. (2009). Informal Employment in Urban China: Heterogeneity and Selectivity. In Towards Gender Equality in Urban China's Economic and Social Transformation: The Rise in Informal Employment and its Impact on Women during Urban China's Economic Transition (pp. 75-103). Beijing, The Heinrich Boll Foundation.

Dickens, W., \& Lang, K. (1985). A Test of Dual Labor Market Theory. American Economic Review, 75 (4), 792-805.

Du, Y., Cai F., \& Wang, M. Y. (2008). Marketization and/or Informalization? New Trends of China's Employment in Transition. Institute of Population and Labor Economics, Chinese Academy of Social Sciences. Retrieved from http://iple.cass.cn/upload/2012/03/d20120305101119714.pdf

Günther, I., \& Launov, A. (2011). Informal Employment in Developing Countries: Opportunity or
Last Resort?. Journal of Development Economics, 97(1), 88-98.

Heckman, J. J. (1979). Sample Selection Bias as a Specification Error. Econometrica, 47(1), 153-161.

Hu, A. G., \& Yang, Y. X. (2001). The employment pattern changes: from formal to informal- China's urban informal employment analysis. Management World, 2001, 2, 69-78.

Hussmanns, R. (2004). Defining and measuring informal employment. E/ESCAP/SOS/11. Geneva: Bureau of Statistics, International Labour Office. Retrieved from http://www.unescap.org/ stat/sos1/sos1_11e.pdf

International Labor Organization. (2002). Decent work and the informal economy. International Labor Conference, 90th Session. Geneva: International Labour Office. Retrieved from http://www.ilo. org/public/english/standards/relm/ilc/ilc90/pdf/ rep-vi.pdf

Lee, L. F. (1983). Generalized Econometric Models with Selectivity. Econometrica, 51 (2), 507-512.

Meng, F. Y. (2003). Path dependence in the change of the labour force migration policy in China. Labour economics and labour relations, 2003 (1), 37-40.

Meng, X., \& Zhang, J. (2001). The Two-Tier Labor Market in Urban China: Occupational Segregation and Wage Differentials between Urban Residents and Rural Migrants in Shanghai. Journal of Comparative Economics, 29 (3), 485-504.

Wang, J. J. (2006). Informal employment under Chinese law. US-China law review, 3 (1), 23-26.

Wu, Y. W., \& Cai, F. (2006). Informal Employment in Urban China: Size and Characteristics. China Labor Economics, 2006 (2), 67-84.

Zuo, H. (in press). Formal and informal employment in China: Probability of employment and determinants of monthly wages. Australian Economic Review. 